\title{
Public Stockholding Regulations and Domestic Agricultural Subsidies in China, India, Brazil and Indonesia to Achieve Food Security in Sustainable Development Goals
}

\author{
M R S Zaki' ${ }^{1}$ H Adolf², A Chandrawulan², S Dewi \\ ${ }^{1}$ Faculty of Humanities, Universitas Bina Nusantara, Jakarta, Indonesia \\ ${ }^{2}$ Faculty of Law, Universitas Padjadjaran, Bandung, Indonesia
}

muhammad.zaki@binus.ac.id

\begin{abstract}
One of the issues related to food in a country is public food reserves or public stockholding. Developing countries with large populations with large responsibilities to meet the food needs of their people. The commonly used strategy is by subsidizing. This subsidy can take the forms of input subsidies such as fertilizer or subsidized output such as food price subsidies. The duties and responsibilities of developing countries with such large populations must then collide with the interests of developed countries, especially those who are exporters of agricultural products. Subsidies given to agricultural products can cause distortions in international markets. This paper covers issues of regulation of Public stockholding and agricultural subsidies in China, India, Brazil, and Indonesia which are developing countries with a large population.
\end{abstract}

Keywords: Subsidies, Developing, Agricultural

\section{INTRODUCTION}

The numbers of people continues to increase year by year. Data from worldbank.org states that in the last 10 years, the population of the earth continues to grow in the range of $1.2 \%$ $1.1 \%$ per year with a downward trend. Although the trend shows a decline, more decline is due to the low rate of population in developed countries such as Europe and North America whose population growth rates are below $1 \%$.

The population growth rate in developing countries such in South Asia, Africa and Latin America is still above $1.2 \%$. This population growth has a close connection with several problems, including the matter of meeting food needs. This problem has even been alluded to by Malthus that the growth in the number of people following the geometry will be much faster than the growth of food that follows the arithmetical series. For developing countries that have a large population, this problem becomes increasingly important to pay attention to. This is because the need for food is a basic human need which cannot be fulfilled.

The Public Stockholding issue is also in order to realize the manifestation of the sustainable development goals in the second point, Zero Hunger and the twelfth point, Responsible Consumption and Production. The comparison of the four countries was carried out to show that countries such as Indonesia, Brazil, China and India are large-populated 
countries that have the potential to experience a food crisis. Unbalanced population and food growth pose a threat to limited food supply.

Developing countries with large populations should be privileged to manage their domestic food. Providing domestic food subsidies in order to support agricultural production that is able to meet national food needs. The government must maintain an environmental balance by creating a policy portfolio that prioritizes the balance of the proportion of development and availability of agricultural land.

\section{METHOD}

The method in this study is normative jurisprudence, where the author examines the legal policy in each country under study. In addition, the author also reviewed the WTO Law, namely Agreement on Agriculture.

\section{RESULTS and DISCUSSION}

\subsection{China}

Every year, China always issued direct directives from the government on what the main agenda will be done by the government in that year. This directive was issued directly by the Chinese communist central committee and the state council, later known as the number 1 central document. For 14 consecutive years-from 2004 to 2017 the main agenda using these documents. This is based on the desire of China to be able to realize food self-sufficiency and overcome the problem of poverty. As explained earlier, China is the country with the largest number of punduduk in the world where almost reaching $1 / 5$ of the world population. The large number of people makes China a major food-producing country and its consumers as well. This is what led to China's release of a white paper in 1996, which deals with issues that could benefit China because of the farmland and the number of farmers they continue to decline. China is optimistic at the moment that they will be able to achieve self-sufficiency, with a target of $95 \%$ of domestic demand being used by domestic production and import conditions.

China has no specific laws that address food security. More food laws in China by maintaining food quality (food safety) such as food safety law 2015. The legal dimensions in China required for the production and control of the food production system.

\subsection{India}

India is one of the most serious countries addressing food security issues. This certainly can not be separated from the fact that India has a very large population. Compared to China which is ranked 1 in terms of population, India is only narrowly lost by 1.37 billion people for China and 1.32 billion people for India. However, if the population density of India is much denser than China, where the population density of China is 146.06 people per square kilometer and India is 440.96 people per square kilometer. This fact further confirms that food security is a strategic issue for India plus the fact that India is home to $1 / 4$ of the world's starving people with 195 million people having malnutrition status in India.

The culmination of India's efforts to alleviate the problem of hunger and malnutrition in its population by seeking food security is by issuing the National Food Security Act (NFSA) 2013. NFSA was endorsed by the Indian parliament on September 10, 2013 with the main 
objective of being the legal basis for India to maintain food security and nutrition for Indian society by ensuring access to appropriate amount of food and affordable prices so that people can live a decent life. This law mandates to provide food and nutritional protection to $75 \%$ of Indians living in rural areas and 50\% of Indians living in urban areas or nearly $2 / 3$ of India's total population. The form of protection provided is to give everyone $5 \mathrm{~kg}$ of food per month at a subsidized price for rice, wheat, and other cereals of Rs. 3/2/1 for each. For distribution system NFSA uses targeted public distribution system (TPDS). In addition to price subsidies on certain food products, NFSA also provides assistance to pregnant and lactating mothers and children under the age of 14 with the help of no less than Rs. 6000.

\subsection{Brazil}

Brazil has raised the issue of food security since the early 1990s. In 1993, Brazil established the National Council on Food and Nutrition Security (CONSEA). At that time Brazil has realized that food security issues will be very important in the future. Although later CONSEA was suspended in 1995 by the then government, its role was reactivated in 2003 during the reign of President LuizInácio Lula da Silva or President Lula. President Lula who came from the background of the labor party at the time really emphasized that the problem of food security is a serious problem for Brazil.

In 2006, Brazil passed federal law for food and nutrition security or LOSAN (Law No. $11346 / 2006)$. One of the messages contained in this LOSAN is about the establishment of the system of food security and nutrition Brazil (SISAN). This SISAN uses a multi-sectoral approach in its efforts to achieve food and nutritional endurance in Brazil. There are two main bodies involved in coordinating this SISAN within three levels of the Brazilian government (federal, state, and municipal). The first is the Inter-ministerial Chamber on Food and Nutritional Security (CAISAN) and the second is Council on Food and Nutritional Security (CONSEA). Brazil's efforts to make food security a very important issue for Brazil finally reached the amendment stage of Brazil's constitution. At amendment No. 64 in 2010, Brazil included the right to food as a basic right of Brazilians. This, of course, makes the legal basis for Brazil to continue its food security and hunger-fighting programs stronger. Brazil is also one of the few countries that entitles food rights to its constitution other than South Africa, Ecuador and Bolivia.

\subsection{Indonesia}

The issue of food security must also be an important issue for Indonesia. as a developing country with a relatively large number of people or no 4 in the world in terms of population, Indonesia has the same reasons as the previous 3 countries discussed in this study to be more concerned about national food security. During the reign of United Indonesia Cabinet vol 2 (KIB 2), food security issues fall into the 11 national development priorities listed in the 20102014 Medium Term Development Plan (RPJMN) 2010-2014. This is what ultimately prompted the government to issue Law No 18 of 2012 on food as one of the legal instruments to underpin government work to address the issue of food security.

Previously, Indonesia already has Law no. 7 of 1996 on food. The new law is a form of change and refinement of the previous law. Some of the differences contained therein are as follows:

Some of the things worth noting in this change are the new laws already existing rules related to price stabilization and the establishment of food reserves which in the previous law 
has not been regulated. Furthermore, the targeted approach used also differs in previous legislation food security is directed to household level, but in the new law the problem of food security is more directed at individual levels per individual. However, the most obvious change is that the new law brings the mandate of a new institution directly responsible to the President of the Republic of Indonesia, the Food Security Agency.

\section{CONCLUSIONS}

Reflecting on these problems there are at least 3 options that might be a solution. The three options are grouped into: 1 . options with the possibility of fewer objections arising and little or no changes in the existing agreements, 2 . Options that can cause long debate and ultimately difficult to resolve, 3. Options where joint agreements are likely can be achieved in certain areas First, in the notifications given to the WTO, the currency units of each country are usually used. There are several countries that choose to submit their notifications in the form of more commonly used currencies such as US \$. This aims to avoid fluctuations that can be caused in exchange rates. In addition, the calculation of production value that is "eligible" can be used by issuing the amount of production directed to the food security program in certain regions. So that only the marketed production is calculated in determining AMS. Second, one of the issues raised by the G-33 countries is the basis for calculation for reference prices. So far the basic price used is in accordance with the Uruguay round (Uruguay Round) in 1986 1988. For this reason, the second solution is to change the base year to be more in line with the current conditions.

This solution is considered to cause a long debate because to determine a new base year, a mutual agreement is needed from all parties. Third, many of the arguments regarding the issue of domestic support issued by developing countries have the same distortion effect as what is done by countries. In fact, developing countries have limited financial capabilities and in some cases their programs have relatively little impact on the market. In addition domestic support programs in developing countries are mostly directed to food security and rarely exported. Therefore, the solution that can be offered is an agreement that the de minimis calculation of developing countries can be eliminated or eliminated provided that their total production does not exceed certain limits. The current de minimis level calculation is based on the country's total production, so if we can determine the amount of production considered appropriate for the country and if the production does not exceed the amount then the distortion effect can be relatively smaller. Each country has a different scheme, purpose, and form - different in achieving their food security program. Therefore, transparency is needed from each country related to their food security program. In fact this transparency has become a problem in this issue. Many countries are not open to their schemes, goals and forms of food security programs.

In addition, for food security programs that do not have the potential to violate the WTO AoA we can take lessons from Brazil. Brazil itself is counted as a successful country in carrying out their food security program, since it began to be echoed in 2003, Brazil currently has a score of 67.7 for their food security index, ranking 38th out of 113 countries. Brazil has a good score in terms of its ability to meet its own domestic needs. At the same time, Brazil is actually counted as a country with relatively low AMS and PSE against other developing countries. The key, Brazil's food security policy is not directed to provide direct assistance in the form of input subsidies or food price support. However, Brazil through its Fome Zero program emphasizes more on agricultural development programs and the farmers themselves such as opening access to capital, education, agricultural insurance and so on. 


\section{ACKNOWLEDGMENTS}

This work was financially supported by Business Law Department, BINUS University

\section{REFERENCES}

[1] Nassar A M, Ures D 2009 Brazil: Shadow WTO Agricultural Domestic Support Notifications IFPRI Discussion Paper 0086537

[2] United Nations and World Food Programme WFP 2012 Online http://in.one.un.org/unpriority-areas-in-India/nutrition-and-food-security/

[3] Department of Food and Public Distribution India 2013 Online http://dfpd.nic.in/nfsaact.htm

[4] FAO 2007 Right to Food: Lessons Learned in Brazil p 1

[5] Global $\quad$ Security $\quad$ Index 2017 Online http://foodsecurityindex.eiu.com/Country/Details\#Brazil

[6] Brink L, Orden D 2017 The United States WTO Complaint on China's Agricultural Domestic Support International Agricultural Trade Research Consortium's 2016 p 14

[7] Brown L R 1995 Who Will Feed China p 35

[8] Ramanujam N, Chow S 2016 Towards A Human Dignity Based Approach to Food Security: Lessons from China and India Frontiers of Law in China 11(2) 1-2

[9] ICTSD 2016 Purposes: Options for a Permanent Solution p 11-12

[10] Montemayor R 2014 Public Stockholding for Food Security p 25

[11] Montemayor R 2014 Public Stockholding for Food Security Purposes: Scenarios and Options for a Permanent Solution Jenewa, Issue Paper 51 ICTSD 31-36

[12] Sumedi, Djauhari A 2014 Reformasi Kebijakan Desentralisasi Sektor Pertanian (Bogor, Badan Penelitian dan Pengembangan Pertanian Kementerian Pertanian) p 322

[13] World Bank 2018 China Online https://data.worldbank.org/country/China

[14] CIA 2018 Online The World Fact Book https://www.cia.gov/library/publications/theworld-factbook/geos/ch.html 